\title{
Offspring produced from heterotopic ovarian allografts in male and female recipient mice
}

\author{
Tracey Waterhouse ${ }^{1}$, Shae-Lee Cox ${ }^{1}$, Melanie Snow ${ }^{1}$, Graham Jenkin ${ }^{1,2}$ and Jill Shaw ${ }^{2}$ \\ ${ }^{1}$ Department of Physiology, Monash University, Victoria 3800, Australia and ${ }^{2}$ Monash Institute of Reproduction \\ and Development, 27-31 Wright Street, Clayton, Victoria 3168, Australia
}

Correspondence should be addressed to S-L Cox; Email: shae.cox@med.monash.edu.au

\begin{abstract}
Studies on human ovarian xenografts and mouse allografts indicate that the male hormonal milieu and exogenous gonadotrophin administration stimulate antral follicle growth. However, it is not known whether oocytes produced under these conditions are developmentally competent. The objective of our study was to evaluate the developmental competence of oocytes produced in heterotopic mouse ovarian grafts placed in male and female recipient mice. Gonadotrophins were $7.5 \mathrm{IU}$ pregnant mare serum gonadotrophin (PMSG) alone or 7.5 IU PMSG and 7.5 IU human chorionic gonadotrophin or were not given prior to oocyte collection. The developmental competence of oocytes was assessed by performing in vitro fertilisation and embryo transfer to recipients. When no gonadotrophins were given the cleavage rate was similar for oocytes collected from ovarian grafts in male and female recipients. Gonadotrophin treatment significantly $(P<0.05)$ increased two-cell formation by oocytes grown in female graft recipients but not in male recipients. Implantation rates, fetal development and the birth of live young were unaffected by the sex of the graft recipient or gonadotrophin treatment. Live offspring were produced from oocytes collected from ovarian grafts in male and female recipients treated with or without gonadotrophins. In conclusion, this work has shown that the hormonal environment of male mice can support the growth of oocytes in ovarian allografts and that these oocytes can produce live offspring.

Reproduction (2004) 127 689-694
\end{abstract}

\section{Introduction}

Cryopreservation and transplantation of ovarian tissue is a promising method for restoring endocrine function and fertility for patients faced with infertility or endocrine disruption due to cancer therapies (Radford et al. 2001, Oktay et al. 2003). Encouraging results from studies in animal models have shown that reproductive cycles are reinitiated and live offspring can be produced from grafts of fresh and cryopreserved ovarian tissue in mice (Parrott 1960, Cox et al. 1996, Gunasena et al. 1997, Candy et al. 2000, Shaw et al. 2000, Snow et al. 2002), sheep (Gosden et al. 1994, Baird et al. 1999, Salle et al. 2002), hamsters (Parrot 1959) and rabbits (Petroianu et al. 2002). Clinical trials in humans have also been initiated and appear promising as fresh and cryopreserved ovarian grafts can restore endocrine function, with ovulation being reported in one case (Oktay \& Karlikaya 2000, Oktay et al. 2003).

In animal models, grafting of ovarian tissue back to the ovarian pedicle allows natural conception to occur (Gosden et al. 1994, Gunasena et al. 1997, Cox et al. 1996, Petroianu et al. 2002, Salle et al. 2002); however, the invasive surgery technique, adhesions and the difficulties in directly monitoring follicle growth at this site have prompted investigation of alternative graft sites. Heterotopic grafting to sites such as the kidney and subcutaneous tissues allows endocrine function to occur (Oktay et al. 2003); in addition, it is also possible to collect oocytes from heterotopic ovarian grafts for fertilisation in vitro (Carroll et al. 1990, Liu et al. 2001).

If heterotopic grafting sites are to be useful in producing oocytes for in vitro fertilisation (IVF), maximising the oocyte yield from the graft by gonadotrophin stimulation would be advantageous as many studies have shown that the lifespan of a graft is limited because of the small size of the graft, follicle loss due to ischaemia after transplantation and, to a lesser extent, cryopreservation of the tissue (Liu et al. 2002).

Testosterone has been shown to promote early follicle growth within the primate ovary (Vendola et al. 1999). Human ovarian tissue xenografted to male mice contains morphologically normal follicles and possesses more preantral and antral follicles after stimulation with human menopausal gonadotrophin (Weissman et al. 1999). Additionally, human (Weissman et al. 1999) and mouse 
(Snow et al. 2002) ovarian tissue xenografted to male rodents treated with exogenous gonadotrophins produce more oocytes per graft than grafts to female recipients, indicating that male recipients may be a better model for increasing oocyte yield from ovarian grafts. While the developmental competence of human oocytes grown in male rodents has not been tested, in the mouse to rat xenograft model oocytes produced from xenografts in male recipients are able to form embryos but fail to give rise to offspring after transfer to pseuodopregnant foster mother mice (Snow et al. 2002).

This study used a mouse allograft model to investigate whether oocytes, matured in ovarian tissue which was grafted heterotopically under the kidney capsule of male and female recipients treated with or without gonadotrophins, could produce live young.

\section{Materials and Methods}

\section{Animals}

Eight-week-old F1 hybrid $(\mathrm{C} 57 \mathrm{bl} \times \mathrm{CBA})$ mice from the Monash University Central Animal Services were used as ovarian tissue donors and as graft recipients (males and females). Females were, wherever possible, used as both a donor and as a recipient of ovarian tissue in order to reduce animal usage. Mice of the same strain were also used for the collection of control ovulated oocytes $(n=16)$, as embryo recipients $(n=32)$ and as sperm donors $(n=15)$. All mice were housed under a $12 \mathrm{~h}$ light: $12 \mathrm{~h}$ darkness regime at $22^{\circ} \mathrm{C}$. Ethical approval for these studies was obtained from the Physiology Animal Ethics Committee of Monash University and conform with the conditions laid down by the NH\&MRC/CSIRO/AAC Australian Code of Practice for the Care and Use of Animals for Scientific Purposes (1997).

\section{Heterotopic allografting procedure}

Donor females were killed by cervical dislocation. The ovaries were removed and placed into PBS (Gibco Life Technologies, Carlsbad, CA, USA) and cut in half. Ovaries were then transplanted underneath the kidney capsule of male and female recipients according to the method previously described by Cox et al. (2000). Briefly, the recipient was anaesthetised with $0.2-0.4 \mathrm{mg}$ Ilium Xylazil-20 (Troy Laboratories, Smithtown, NSW, Australia) and 1$2 \mathrm{mg}$ ketamine (Parnell Laboratories, Alexandria, NSW, Australia) in sterile PBS. A dorsolateral incision was made into the skin and peritoneum to expose the ovary and kidney. A small incision was made into the kidney capsule and one or two half pieces of ovary were inserted under the capsule. The kidney was returned to its normal anatomical position. This was repeated on the other kidney. All female recipients had both of their in situ ovaries surgically removed at the time of grafting. These ovaries were either discarded or used as donor tissue for grafting to another recipient. The gonads of all male recipients remained intact. The skin incision was closed with $9 \mathrm{~mm}$ Michel clips (Clay Adams, Sparks, MD, USA).

\section{Gonadotrophin treatment}

Nineteen days after grafting, recipients were divided into six groups. Mice that were treated with gonadotrophins were given a single i.p. injection of $7.5 \mathrm{IU}$ pregnant mare serum gonadotrophin (PMSG) (Folligon; Intervet, Castle Hill, NSW, Australia) with or without 7.5 IU human chorionic gonadotrophin (hCG) (Chorulon; Intervet) $48 \mathrm{~h}$ later. Mice receiving PMSG only were killed $48 \mathrm{~h}$ later and mice receiving PMSG $+\mathrm{hCG}$ were killed $12 \mathrm{~h}$ after the hCG injection.

The experimental groups were as follows: female PMSG only $(n=12)$; male PMSG only $(n=8)$; female PMSG + hCG $(n=4)$, male PMSG + hCG $(n=4)$; female no gonadotrophins $(n=8)$; male no gonadotrophins $(n=9)$. All recipients were killed 21 days after grafting. Twenty-one days was chosen as this has been shown to be the time taken for primordial follicles to reach the preovulatory stage in the mouse after grafting (Cox et al. 2000).

Control animals did not receive any ovarian grafts. They were age-matched females of the same strain which were killed without any treatment (control no gonadotrophins, $n=7$ ) or $48 \mathrm{~h}$ after a single PMSG injection (control PMSG only, $n=11$ ). The ovaries were then removed, placed in M2 handling medium (Quinn et al. 1982, Nagy et al. 2003), and all visible follicles then punctured with needles to release the oocytes.

\section{Oocyte collection and in vitro maturation}

The grafts were collected into $\mathrm{M} 2$ handling medium at $37^{\circ} \mathrm{C}$. The antral follicles were punctured with 26 guage needles to release oocytes. At the time of collection, oocytes fell into two groups: fully cumulus enclosed (tight cumulus cells) for which the nuclear status could not be assessed and oocytes that were partially surrounded or devoid of cumulus cells. The later could be scored for nuclear status. All oocytes were cultured in 20-30 $\mu$ l droplets of $\alpha$-Eagles' minimum essential medium (Sigma, St Louis, MO, USA) supplemented with $10 \%$ fetal calf serum (v/v; Sigma), $1 \mathrm{IU} / \mathrm{ml}$ PMSG and $1 \mathrm{IU} / \mathrm{ml}$ hCG covered with a layer of mineral oil (Sigma) and incubated for $18 \mathrm{~h}$ at $37^{\circ} \mathrm{C}, 100 \%$ humidity and $5 \% \mathrm{CO}_{2}$ in air. Throughout the experiments $35 \mathrm{~mm}$ Falcon culture dishes (Becton Dickinson, Franklin Lakes, NJ, USA) were used.

The control group of mice given PMSG only or no gonadotrophins were killed by cervical dislocation and their ovaries removed and placed immediately into $\mathrm{M} 2$ handling medium. Oocytes were released from antral follicles by puncturing the follicles with fine needles. At the time of collection, oocytes were scored as for the experimental groups. All oocytes were taken for in vitro maturation at the same time as the oocytes collected from the ovarian grafts. 


\section{Sperm preparation}

Male mice were killed by cervical dislocation and the testes removed. The cauda of the epididymis were dissected free, cut into strips and each cauda placed into $1 \mathrm{ml}$ modified tyrodes solution (mT6; Quinn et al. 1982) in $6 \mathrm{ml}$ Falcon tubes (Becton Dickinson). The sperm were incubated at $37^{\circ} \mathrm{C}, 100 \%$ humidity, $5 \% \mathrm{CO}_{2}$ in air for $30-$ 60 min. mT6 insemination drops were then prepared by placing $30 \mu \mathrm{l}$ aliquots of this medium containing the sperm into $35 \mathrm{~mm}$ Falcon dishes and then covering them with pre-equilibrated mineral oil.

\section{IVF and embryo culture}

The oocytes were washed in two or three $20 \mu \mathrm{l}$ preincubated droplets of mT6 medium before being placed into a droplet containing sperm. Two hours later the oocytes were washed two to three times in preincubated $20 \mu \mathrm{l}$ droplets of M16 medium (Nagy et al. 2003) supplemented with BSA (fraction V; Bayer, West Haven, CT, USA) and then cultured for $24 \mathrm{~h}$. The number of resulting two-cell embryos was then scored.

Fertilisation of the oocytes from the ovarian grafts was performed at the same time as the collection and fertilisation of ovulated oocytes from the oviducts of (superovulated) age-matched mice of the same strain. These mice were superovulated with an i.p. injection of 7.5 IU PMSG (Folligon) followed $48 \mathrm{~h}$ by an i.p. injection of $7.5 \mathrm{IU}$ hCG (Chorulon) and killed by cervical dislocation 13-14h later. The oviducts were removed and placed into M2 medium and the cumulus mass released by puncturing the ampulla. These metaphase II (MII) oocytes served as controls for the in vitro maturation procedures and were therefore fertilised with the same sperm as the oocytes that were collected from the ovarian grafts.

\section{Embryo transfer}

Pseudopregnant embryo transfer recipients were obtained by placing normal 7- to 12-week-old virgin F1 females with vasectomised males of the same strain. On the day of mating (evidenced by the presence of a vaginal plug at $0900 \mathrm{~h}$ ) the pseudopregnant females were anaesthetised as described above and the two-cell embryos were inserted into the oviducts with a fine glass pipette. Pseudopregnant recipients (foster mothers) had two-cell embryos from one of the control groups inserted into the one oviduct and two-cell embryos from one of the male or female ovarian graft groups placed into the contralateral oviduct. These recipients were killed 14 days later so that the number of fetuses and implantation sites could be recorded. The normality and weight of the fetuses was also noted. In a separate trial, the no gonadotrophin and the PMSG only groups for the male and female recipient and the control groups were transferred to foster mothers and the pregnancy allowed to go to term. These recipients had embryos from only one treatment or control group transferred to both oviducts. Offspring were killed at weaning age.

\section{Statistical analysis}

The percentages of oocytes at each stage of development were calculated from independent replicate experiments. In each group, the data were pooled and the Chi-square test was used to compare the number of two-cell embryos, fetuses and offspring born between comparable groups. $P \leq 0.05$ was considered significantly different.

\section{Results}

A total of 298 and 287 oocytes were collected from a total of 78 and 77 grafts in male and female recipients respectively. The majority of oocytes collected were either partially enclosed by cumulus cells or totally devoid of cumulus cells and all were at the geminal vesicle (GV) stage of development $(78.5 \%$ female groups and $74.5 \%$ male groups). The remainder of the oocytes were completely enclosed by cumulus cells and so the nuclear status could not be assessed. The cumulus cells attached to these completely enclosed oocytes were not fully expanded.

\section{Male recipient groups}

In the male group of graft recipients, 107, 155 and 36 oocytes were collected from 34/36, 32/32 and 12/16 grafts from the no gonadotrophin, PMSG only and PMSG + hCG groups respectively. After IVF, 44, 49 and 18 two-cell embryos formed in the no gonadotrophin, PMSG only and PMSG + hCG groups respectively. Normal fetuses developed in all groups after embryo transfer (Table 1). Fourteen embryos were transferred in each of the no gonadotrophin and PMSG only groups, in which the pregnancy was allowed to go to term and resulted in two and three pups respectively. In each group, all fetuses and/or pups born were phenotypically normal.

The Chi-square test was performed on the number of two-cell embryos that developed in each group. The proportion of two-cell embryos in the male PMSG + hCG group was significantly higher than the male PMSG only group. When compared with the control groups, the number of two-cell embryos produced was lower in the male graft recipient groups given gonadotrophins (control PMSG only vs male PMSG only, $P \leq 0.025$; control PMSG + hCG vs male PMSG + hCG, $P \leq 0.001)$. Similarly, when the female and male recipient groups were compared, the proportion of two-cell embryos was lower in the male graft recipient groups that were given gonadotrophins (female PMSG only vs male PMSG only, $P \leq 0.001$; female PMSG + hCG vs male PMSG + hCG, $P \leq 0.05)$.

\section{Female recipient groups}

In the female group of recipients, 103, 165 and 19 oocytes were collected from 24/24, 46/48 and 7/8 grafts from the no gonadotrophin, PMSG only and PMSG + 
Table 1 Developmental capacity of oocytes collected from ovarian grafts in male and female recipient mice.

\begin{tabular}{|c|c|c|c|c|c|c|}
\hline Group & $\begin{array}{l}\text { No. of oocytes } \\
\text { collected }\end{array}$ & $\begin{array}{l}\text { No. }(\%) \mathbf{G V}^{*} \text { at } \\
\text { collection }\end{array}$ & $\begin{array}{c}\text { No. }(\%) \text { of two-cell } \\
\text { embryos after IVM and IVF }\end{array}$ & $\begin{array}{l}\text { No. of embryos } \\
\text { transferred }\end{array}$ & $\begin{array}{l}\text { No. }(\%) \\
\text { implanted }\end{array}$ & $\begin{array}{l}\text { No. }(\%) \\
\text { of fetuses }\end{array}$ \\
\hline \multicolumn{7}{|l|}{ Male } \\
\hline No gonadotrophins & 107 & $68(63.5)$ & $44^{\mathrm{ab}}(41.1)$ & 9 & $3^{\mathrm{a}}(33.3)$ & $3^{\mathrm{a}}(33.3)$ \\
\hline PMSG only & 155 & $118(76.1)$ & $49^{\mathrm{a} \neq}(31.6)$ & 27 & $12^{\mathrm{a}}(44.4)$ & $5^{a}(18.5)$ \\
\hline PMSG + hCG & 36 & $28(77.7)$ & $18^{\mathrm{b} \neq}(50)$ & 15 & $6^{\mathrm{a}}(40)$ & $4^{\mathrm{a} \neq}(26.6)$ \\
\hline \multicolumn{7}{|l|}{ Female } \\
\hline No gonadotrophins & 103 & $76(73.7)$ & $54^{\mathrm{a}}(52.4)$ & 6 & $4^{\mathrm{a}}(66.6)$ & $4^{\mathrm{a}}(66.6)$ \\
\hline PMSG only & 165 & $143(86.6)$ & $99^{\mathrm{ab} \neq}(60)$ & 68 & $45^{a}(66.2)$ & $15^{\mathrm{b}}(22)$ \\
\hline PMSG + hCG & 19 & $15(78.9)$ & $15^{\mathrm{b}}(78.9)$ & 12 & $5^{a}(41.6)$ & $3^{a b \neq}(25)$ \\
\hline \multicolumn{7}{|l|}{ Control IVM and IVF } \\
\hline No gonadotrophins & 119 & $86(72.3)$ & $55^{\mathrm{b}}(46.2)$ & 16 & $13^{\mathrm{ab}}(81.3)$ & $7^{\mathrm{a}}(43.8)$ \\
\hline PMSG only & 135 & $95(70.3)$ & $61^{\mathrm{b}}(45.2)$ & 22 & $12^{\mathrm{b}}(54.5)$ & $4^{b}(18.2)$ \\
\hline $\begin{array}{l}\text { Ovulated oocytes } \\
\text { (PMSG and hCG) }\end{array}$ & 309 & $0(0)^{* *}$ & $274^{\mathrm{a}}(88.6)$ & 113 & $99^{a}(87.6)$ & $78^{\mathrm{a}}(69)$ \\
\hline
\end{tabular}

*The remainder were oocytes fully enclosed by tight cumulus cells. ${ }^{\dagger}$ At day 14 after embryo transfer. IVM, in vitro matured.

$\mathrm{a}, \mathrm{b} P<0.05$ within each column and within each group; ${ }^{\ddagger} P<0.05$ compared with corresponding control group. ${ }^{* *}$ These oocytes were MII with expanded cumulus at the time of collection from the oviduct.

hCG groups respectively. Two-cell embryos were produced in all groups after IVF (54, no gonadotrophins; 99, PMSG only; 15, PMSG + hCG). Significantly more two-cell embryos developed in the female PMSG + hCG group compared with the female no gonadotrophin group. More two-cell embryos developed in the female graft recipients given PMSG only, when compared with the control group given PMSG only $(P \leq 0.025)$. Normal fetuses developed in all groups. Seven pups were born in each of the no gonadotrophin and PMSG only groups. All fetuses and pups were phenotypically normal.

\section{Control groups}

In the non-grafted control groups of mice, 119, 135 and 309 oocytes were collected, of which 55, 61 and 274 formed into two-cell embryos in the no gonadotrophin, PMSG only and ovulated oocyte groups respectively. The proportion of two-cell embryos that developed in the control group treated with PMSG + hCG was higher than that in the control group treated with PMSG only $(P \leq 0.001)$ and the control group without gonadotrophins $(P \leq 0.001)$. Phenotypically normal fetuses and pups were produced in these groups (Table 2).

\section{Discussion}

We obtained live offspring after IVF of oocytes grown in ovarian tissue grafted under the kidney capsule of male recipients. This demonstrated that the male hormonal environment can support the production of developmentally competent oocytes.

Live young have been obtained from fresh and frozen ovarian tissue grafted to orthotopic or heterotopic locations in females (Parrott 1959, 1960, Carroll et al. 1990, Gosden et al. 1994, Cox et al. 1996, Gunasena et al. 1997, Baird et al. 1999, Candy et al. 2000, Shaw et al. 2000, Salle et al. 2002, Snow et al. 2002). As grafts at heterotopic locations do not allow spontaneous conception, the oocytes have to
Table 2 Number of pups born at term after embryo transfer $(n=14)$.

\begin{tabular}{ll}
\hline Group & No. of pups $(\%)$ \\
\hline Male & \\
No gonadotrophins & $2(14)^{\mathrm{a} \ddagger}$ \\
PMSG only & $3(21)^{\mathrm{a}}$ \\
Female & $7(50)^{\mathrm{a}}$ \\
No gonadotrophins & $7(50)^{\mathrm{a}}$ \\
PMSG only & $3(21)^{\mathrm{a}}$ \\
Control IVM & $5(36)^{\mathrm{a}}$ \\
$\quad$ No gonadotrophins & \\
PMSG only &
\end{tabular}

${ }^{\text {a }} P>0.05$ within each column and within each group. ${ }^{\ddagger} P<0.05$ compared with female no gonadotrophin group.

be harvested for IVF and embryo transfer. As in other situations where assisted reproduction is used, it is desirable to maximise the likelihood of generating viable embryos for transfer by maximising the number and quality of oocytes that can be collected, while also minimising the length of time that the oocytes take to be recruited and develop into full-sized antral follicles (Nugent et al. 1998, Liu et al. 2002).

Testosterone and dihydrotestosterone have a stimulatory effect on primordial follicle recruitment in the ovary (Vendola et al. 1999), and can promote early embryo cleavage in vitro (Silva \& Knight 2000). Previous studies on human ovarian xenografts indicated that significantly more preantral and large antral follicles were present within grafts to males than grafts to female recipients (Weissman et al. 1999). However, when mouse ovarian tissue was xenografted to male recipient rats significantly fewer ovarian xenografts were recovered from male $(<10 \%)$ than from female recipients $(>78 \%)$. The oocytes from these male xenografts did cleave following insemination but neither of the embryos that were transferred implanted (Snow et al. 2002). Thus the viability of oocytes grown in male recipients was questioned. The results of this current study 
found that mouse oocytes grown in male recipients could be fertilised, and implant and develop into fetuses and live young, showing that the hormonal environment of male mice can support the growth of oocytes in ovarian allografts.

Reports on the effect of testosterone on oocytes cultured in vitro are varied and have only dealt with the final stages of oocyte maturation. In the mouse and pig, physiological levels of testosterone do not affect the developmental competence of in vitro cultured oocytes (Anderiesz \& Trounson 1995, Herrick \& Pope 2002). Studies in the cow have found that the addition of physiological concentrations of androgens to the in vitro culture medium increases embryo cleavage rates; however, the proportion of cleaved oocytes that reach the blastocyst stage was not affected (Silva \& Knight 2000), whereas supraphysiological levels of testosterone reduce the ability of mouse oocytes to undergo normal maturation and development to the blastocyst stage of embryogenesis (Anderiesz \& Trounson 1995).

Primordial follicles are the main survivors in ovarian grafts, with fewer growing follicles surviving the ischaemic conditions post transplantation (Liu et al. 2002). Since grafts in this present study were collected 3 weeks after transplantation (the time taken for primordial follicles to reach the preovulatory stage) and none of the grafts contained corpora lutea, the oocytes collected would have thus developed from primordial follicles and hence have been exposed to androgens throughout most of their growth phase. Despite this relatively long-term exposure to androgens, developmentally competent oocytes were produced in ovarian tissue grafted to intact male recipients. Fetal development and birth of live young were similar for oocytes grown in grafts placed in male and female recipients with or without gonadotrophin stimulation.

Gonadotrophin treatment of recipients showed differing effects on embryogenesis in the male and female groups. In the female recipient groups, PMSG + hCG stimulation resulted in the highest number of two-cell embryos that formed in the treatment groups, being comparable with that observed in ovulated oocytes $(78.9 \%$ vs $88.6 \%$ respectively). In the male recipient groups, treatment with gonadotrophins did not improve two-cell embryo rates, with PMSG alone causing a reduction in the two-cell cleavage rate. This may indicate that there is an interaction between testosterone and gonadotrophins that affects oocyte competence. In the monkey, testosterone treatment of individually cultured follicles significantly increases follicle-stimulating hormone (FSH) receptor mRNA in granulosa cells, suggesting that testosterone may alter follicle responsiveness to FSH stimulation (Weil et al. 1999). In adult rhesus monkeys that have been androgenised during prenatal development, stimulation with recombinant FSH results in reduced levels of oestrogen and androstenedione in the follicular fluid and subsequent impairment of blastocyst development after IVF (Dumesic et al. 2002, 2003). In this present study, while not measured, it may be possible that the administration of gonadotrophins to male mice with ovarian grafts results in alterations in the ratio and concentration of sex steroids in the follicular fluid which could affect oocyte development.

The developmental competence of oocytes was lower in all the graft groups compared with ovulated oocytes (control PMSG + hCG group) from ungrafted ovaries. This may, in part, be due to the oocytes from grafts undergoing in vitro maturation or an effect of grafting per se. An interesting observation was that the majority of oocytes collected from the grafts in male and female recipients treated with PMSG and hCG were at the GV stage similar to the PMSG only and no gonadotrophin groups (Table 1). This indicates that germinal vesicle breakdown which normally follows hCG administration does not occur in ovarian grafts within the expected time frame. Oocytes were collected from antral follicles $12 \mathrm{~h}$ post hCG injection in order to avoid ovulation (and loss) of the oocytes into the subcapsular space of the kidney or the abdominal cavity. It is believed that the extrusion of the first polar body in the mouse can occur in vivo from $10 \mathrm{~h}$ post hCG injection (Nagy et al. 2003). However, Carroll et al. (1990) reported that primary follicles grown to the antral stage under the kidney capsule of female recipients were mainly at the GV stage of development after stimulation with PMSG followed by hCG and collected 12-14 h later. Similarly, Snow et al. (2002) found that heterotopic mouse ovarian xenografts failed to produce an increase in oocyte yield in response to exogenous PMSG treatment. Collectively, these studies may indicate that the follicular/oocyte response to exogenous gonadotrophins at a heterotopic site may not be normal. The reason for this is unclear. Allo- and autografts at orthotopic sites do, however, respond to endogenous gonadotrophins as they undergo spontaneous ovulation in vivo as evidenced by the presence of corpora lutea in the grafts and birth of live young (Parrott 1959, 1960, Gosden et al. 1994, Cox et al. 1996, Jenkin et al. 1996, Gunasena et al. 1997, Candy et al. 2000, Shaw et al. 2000, Salle et al. 2002, Petroianu et al. 2002).

In summary, this study has shown that mouse ovarian tissue grafted to male and female recipients is capable of producing developmentally competent oocytes which have the ability to undergo normal embryogenesis, fetal development and give rise to live young.

\section{Acknowledgements}

This research was supported by an Australian Research Council Large Grant. We thank Dr Orly Lacham-Kaplan for assistance with the IVF techniques and Mr David Caddy for statistical advice.

\section{References}

Anderiesz C \& Trounson AO 1995 The effect of testosterone on the maturation and developmental capacity of murine oocytes in vitro. Human Reproduction 10 2377-2381.

Baird DT, Webb R, Campbell BK, Harkness LM \& Gosden RG 1999 Long-term ovarian function in sheep after ovariectomy and 
transplantation of autografts stored at $-196 \mathrm{C}$. Endocrinology $\mathbf{1 4 0}$ $462-471$.

Candy CJ, Wood MJ \& Whittingham DG 2000 Restoration of a normal reproductive lifespan after grafting of cryopreserved mouse ovaries. Human Reproduction 15 1300-1304.

Carroll J, Whittingham DG, Wood MJ, Telfer E \& Gosden RG 1990 Extra-ovarian production of mature viable mouse oocytes from frozen primary follicles. Journal of Reproduction and Fertility 90 $321-327$.

Cox SL, Shaw J \& Jenkin G 1996 Transplantation of cryopreserved fetal ovarian tissue to adult recipients in mice. Journal of Reproduction and Fertility 107 315-322.

Cox S, Shaw J \& Jenkin G 2000 Follicular development in transplanted fetal and neonatal mouse ovaries is influenced by the gonadal status of the adult recipient. Fertility and Sterility $\mathbf{7 4}$ 366-371.

Dumesic DA, Schramm RD, Peterson E, Paprocki AM, Zhou R \& Abbott DH 2002 Impaired developmental competence of oocytes in adult prenatally androgenized female rhesus monkeys undergoing gonadotropin stimulation for in vitro fertilization. Journal of Clinical Endocrinology and Metabolism 87 1111-1119.

Dumesic DA, Schramm RD, Bird IM, Peterson E, Paprocki AM, Zhou R \& Abbott DH 2003 Reduced intrafollicular androstenedione and estradiol levels in early-treated prenatally androgenized female rhesus monkey receiving follicle-stimulating hormone therapy for in vitro fertilization. Biology of Reproduction 69 1213-1219.

Gosden RG, Baird DT, Wade JC \& Webb R 1994 Restoration of fertility to oophorectomized sheep by ovarian autografts stored at - 196 degrees C. Human Reproduction 9 597-603.

Gunasena KT, Villines PM, Critser ES \& Critser JK 1997 Live births after autologous transplant of cryopreserved mouse ovaries. Human Reproduction 12 101-106.

Herrick JR \& Pope WF 2002 Exposure to androgens during in vitro maturation does not affect the developmental potential of porcine oocytes. Theriogenology 58 1131-1139.

Jenkins G, Cox S-L \& Shaw J 1996 Transplantation of fetal ovarian tissue. Singapore Journal of Obstetrics and Gynaecology 27 85-91.

Liu J, Van der Elst J, Van den Broecke R \& Dhont M 2001 Live offspring by in vitro fertilization of oocytes from cryopreserved primordial mouse follicles after sequential in vivo transplantation an in vitro maturation. Biology of Reproduction 64 171-178.

Liu J, Van der Elst J, Van den Broecke R \& Dhont M 2002 Early massive follicle loss and apoptosis in heterotopically grafted newborn mouse ovaries. Human Reproduction 17 605-611.

Nagy A, Gersenstein M, Vintersten K \& Behringer R 2003 Manipulating the Mouse Embryo: A Laboratory Manual, p 179-185. New York: Cold Spring Harbor Laboratory Press.

Nugent D, Newton H, Gallivan L \& Gosden RG 1998 Protective effect of vitamin E on ischaemia-reperfusion injury in ovarian grafts. Journal of Reproduction and Fertility 114 341-346.

Oktay K \& Karlikaya G 2000 Ovarian function after transplantation of frozen, banked autologous ovarian tissue. New England Journal of Medicine 3421919.
Oktay K, Buyuk E, Rosenwaks Z \& Rucinski J 2003 A technique for transplantation of ovarian cortical strips to the forearm. Fertility and Sterility 80 193-198.

Parrott DMV 1960 The fertility of mice with orthotopic ovarian grafts derived from frozen tissue. Journal of Reproduction and Fertility 1 230-241.

Parrott DM 1959 Orthotopic ovarian grafts in the golden hamster. Journal of Endocrinology 19 126-138.

Petroianu A, de Souza Vasconcellos L, Alberti LR, Fonseca de Castro LP \& Barbosa Leite JM 2002 Natural pregnancy in rabbits that underwent oophorectomy and orthotopic allogeneic or autologous ovarian transplantation. Fertility and Sterility 77 1298-1299.

Quinn P, Barros C \& Whittingham DG 1982 Preservation of hamster oocytes to assay the fertilizing capacity of human spermatozoa. Journal of Reproduction and Fertility 66 161-168.

Radford JA, Lieberman BA, Brison DR, Smith AR, Critchlow JD, Russell SA, Watson AJ, Clayton JA, Harris M, Gosden RG \& Shalet SM 2001 Orthotopic reimplantation of cryopreserved ovarian cortical strips after high-dose chemotherapy for Hodgkin's lymphoma. Lancet 357 1172-1175.

Salle B, Demirci B, Franck M, Rudigoz RC, Guerin JF \& Lornage J 2002 Normal pregnancies and live births after autograft of frozenthawed hemi-ovaries into ewes. Fertility and Sterility 77 403-408.

Shaw JM, Cox SL, Trounson AO \& Jenkin G 2000 Evaluation of the long-term function of cryopreserved ovarian grafts in the mouse, implications for human applications. Molecular and Cellular Endocrinology 161 103-110.

Silva CC \& Knight PG 2000 Effects of androgens, progesterone and their antagonists on the developmental competence of in vitro matured bovine oocytes. Journal of Reproduction and Fertility 119 261-269.

Snow M, Cox SL, Jenkin G, Trounson A \& Shaw J 2002 Generation of live young from xenografted mouse ovaries. Science 297 2227.

Vendola K, Zhou J, Wang J, Famuyiwa OA, Bievre M \& Bondy CA 1999 Androgens promote oocyte insulin-like growth factor I expression and initiation of follicle development in the primate ovary. Biology of Reproduction $61353-357$.

Weil S, Vendola K, Zhou J \& Bondy CA 1999 Androgen and follicle stimulating hormone interactions in primate ovarian follicle development. Journal of Clinical Endocrinology and Metabolism 84 2951-2956.

Weissman A, Gotlieb L, Colgan T, Jurisicova A, Greenblatt EM \& Casper RF 1999 Preliminary experience with subcutaneous human ovarian cortex transplantation in the NOD-SCID mouse. Biology of Reproduction 60 1462-1467.

Received 7 November 2003

First decision 7 January 2004

Revised manuscript received 4 March 2004

Accepted 22 March 2004 